\title{
Microstructure and Mechanical Behavior of Hot Pressed Cu-Sn Powder Alloys
}

\author{
Ahmed Nassef and Medhat El-Hadek \\ Department of Production \& Mechanical Design, Faculty of Engineering, Port Said University, Port Fouad, Port Said 42523, Egypt \\ Correspondence should be addressed to Medhat El-Hadek; melhadek@eng.psu.edu.eg
}

Received 31 January 2016; Revised 26 March 2016; Accepted 30 March 2016

Academic Editor: Angela De Bonis

Copyright ( 2016 A. Nassef and M. El-Hadek. This is an open access article distributed under the Creative Commons Attribution License, which permits unrestricted use, distribution, and reproduction in any medium, provided the original work is properly cited.

$\mathrm{Cu}-\mathrm{Sn}$ based alloy powders with additives of elemental $\mathrm{Pb}$ or $\mathrm{C}$ were densified by hot pressing technique. The influence of densifying on the properties of the hot pressed materials was investigated. The properties, such as the hardness, compressive strength, and wear resistance of these materials, were determined. The hot pressed $\mathrm{Cu}$-Sn specimens included intermetallic/phases, which were homogeneously distributed. The presence of graphite improved the wear resistance of Cu-Sn alloys three times. Similarly, the presence of lead improved the densification parameter of $\mathrm{Cu}-\mathrm{Sn}$ alloys three times. There was no significant difference in the mechanical behavior associated with the addition of $\mathrm{Pb}$ to the $\mathrm{Cu}-\mathrm{Sn}$ alloys, although $\mathrm{Cu}-\mathrm{Pb}$ alloys showed considerably higher ultimate strength and higher elongation. The $\mathrm{Cu}-\mathrm{Sn}-\mathrm{C}$ alloys had lower strength compared with those of $\mathrm{Cu}-\mathrm{Sn}$ alloys. Evidence of severe melting spots was noticed in the higher magnifications of the compression fracture surface of $85 \% \mathrm{Cu}-10 \% \mathrm{Sn}-5 \% \mathrm{C}$ and $80 \% \mathrm{Cu}-10 \% \mathrm{Sn}-10 \% \mathrm{~Pb}$ alloys. This was explained by the release of load at the final event of the fracture limited area.

\section{Introduction}

Metal matrix composites had attracted the interest of material scientists in the last few decades due to its unique properties $[1,2]$. The motivations behind developing metal matrix composites were to fabricate structures that have superior stiffness and to simultaneously have better toughness and structural integrity $[3,4]$. Copper alloy powders have been used in industrial applications for many years, as they have high corrosion resistance, high ductility, moderate to high hardness and strength behavior, high thermal and electrical conductivity, and high fatigue and abrasion resistance [5]. Copper matrix composites had been considered as one of the appealing candidates in various applications [5-7]. Tin $(\mathrm{Sn})$ is a malleable, ductile, and highly crystalline silvery white metal. It has a relatively low melting point of $231^{\circ}$ compared to copper $(\mathrm{Cu})$ which has a melting temperature of $1084^{\circ} \mathrm{C}$. Tin resists corrosion from water but can be affected by acids and alkalis $[5,8]$. Tin could be highly polished and was used as a protective coating layer for other metals [9]. In this case, the protective oxide layer prevents further oxidation, as it acts as a catalyst when oxygen is in the solution and helps to accelerate the chemical attack [9]. Accordingly, the composites produced from the combination of these materials are expected to possess superior properties for various industrial applications [10]. Cu-Sn alloys have been widely used as self-lubricant materials for many years [5], and powder metallurgy (PM) has been the main process to fabricate these alloys. The mechanical properties of copper represent the key factor in determining the suitability of the composite materials especially in applications where the material was subjected to high loads and frictions [11]. Copper reinforced with fine and uniform tin dispersoids has shown remarkable thermal and mechanical stability at an elevated temperature as reported by Xie et al. [12]. They reported that the monotonic shear behavior of asreflowed $\mathrm{Cu}-\mathrm{Sn}$ exhibits high strain to failure values [12]. The microstructure of the $\mathrm{Cu}-\mathrm{Sn}$ alloys has shown a gradual cellular to dendritic transition which reflects stabilization in the growth [13]. This leads to an increase in the ultimate tensile strengths associated with finer eutectic cells for $\mathrm{Cu}$ Sn alloys [13]. Recently, Kim et al. [14] introduced graphite to $\mathrm{Cu}-\mathrm{Sn}$ alloys to improve thermal properties. These new composites have proven to be very useful in the lithium ion 
batteries applications $[15,16]$. The graphite addition improves the wear resistance. The density, impact toughness, and hardness decrease with increasing the $\mathrm{C}$ content. The impact toughness has a maximum value of $11.7 \mathrm{~J} / \mathrm{Cm}^{2}$ at $2 \% \mathrm{C}$ and a minimum value of $4.3 \mathrm{~J} / \mathrm{Cm}^{2}$ at $6 \% \mathrm{C}$ [17]. Leaded bronzes $(\mathrm{Cu}-\mathrm{Sn}-\mathrm{Pb})$ were mainly used for bearings due to their good wear resistance. For wide range of solidification, $\mathrm{Cu}-\mathrm{Sn}$ alloys are extremely difficult to be produced by casting. However, because of the wide temperature range of crystallization and the large difference in the densities of copper and lead, intensive segregation takes place during solidification of $\mathrm{Cu}$ $\mathrm{Pb}$ alloys [17]. Consequently, it was difficult to obtain homogeneous distribution of $\mathrm{Pb}$ in the microstructure by melting and casting. Therefore, powder metallurgy offers a promising processing route for producing such parts. The lead, the insoluble graphite in copper, and their additions to $\mathrm{Cu}-\mathrm{Sn}$ alloys have some advantages in developing antifriction alloys especially by powder metallurgy. The powder metallurgy (PM) processing technique has definite advantages when used for consolidation of prealloyed powders.

The production of such composites via the conventional melting and casting techniques was extremely difficult as a result of the nonhomogenous distribution of the dispersoids. This leads to lowering the mechanical properties of the produced composites [18]. The suitability in controlling the homogeneous distribution of different materials in the PM depends on the technique used in preparing such composites [19]. Although the use of PM techniques proved to be the best in producing a homogeneous distribution of reinforced materials in the final product, this process alone has not given convenient results $[18,19]$ especially with reinforced materials having extremely fine particles. A few trials, such as mechanical alloying or rapid solidification, have been examined $[19,20]$ but have often shown a contamination and poor economic efficiency [18]. Generally, compaction is one of the most widely used techniques to obtain powder products. The well-known press and sintering technique was widely used to obtain dense products, but difficulties may arise especially in the sintering stages. The hot compaction technique densification has two stages. In the first stage, rearrangement of particles takes place by sliding and local plastic deformation of grain surface irregularities. At the second stage, the relative motion among particles becomes very small as the relative density increases [21, 22].

The scope of this research study was to manufacture four different $\mathrm{Cu}-\mathrm{Sn}$ metal matrix composites using hot pressed powder alloying process, namely, $90 \% \mathrm{Cu}-10 \% \mathrm{Sn}$ with no additions, 85\% Cu-10\% Sn-5\% C, 80\% Cu-10\% Sn-10\% Pb, and $90 \% \mathrm{Cu}-10 \% \mathrm{~Pb}$ weight percentages. The effect of the carbon and lead addition on the microstructure was studied. The effect of graphite or lead particles powder in addition to the $\mathrm{Cu}-\mathrm{Sn}$ metal matrix composites was investigated on the hardness, mechanical, and wears properties.

\section{Materials and Methods}

Elemental $\mathrm{Cu}, \mathrm{Sn}, \mathrm{C}$, and $\mathrm{Pb}$ possess strong ionic interatomic bonding giving rise to desirable material characteristics.
Powders with purity greater than $99 \%$ with an average particle size less than $10 \mu \mathrm{m}$ in diameter and manufactured by Alfa Aesar, USA, were used as the starting source materials. The various powder components were mechanically mixed forming the nominal composition, namely, 90\% Cu-10\% Sn with no additions, $85 \%$ Cu-10\% Sn-5\% C, $80 \%$ Cu-10\% Sn$10 \% \mathrm{~Pb}$, and $90 \% \mathrm{Cu}-10 \% \mathrm{~Pb}$ weight percentages. To ensure uniformity of the particle shapes, the $\mathrm{Cu}, \mathrm{Sn}, \mathrm{C}$, and $\mathrm{Pb}$ powders were mechanically milled and mixed in an agate rock mortar with high energy boll milled for half an hour with different weight ratios according to the composition design. The mechanical milling of the powders resulted in uniform sphere-like particles for $\mathrm{Cu}-\mathrm{Sn}$ alloys. Figure 1 presents the (a) scanning electron microscopy (SEM) surface microstructure of $\mathrm{Cu}-\mathrm{Sn}$ alloys, as the red arrows pointing to the semisolid tin during the electroless process, (b) the graphite particle, (c) the lead particle as uniform spherical shape, (d) $\mathrm{Cu}-\mathrm{Sn}$ alloys with graphite particles, and (e) $\mathrm{Cu}-\mathrm{Sn}$ alloys with lead particles during the electroless process.

The process starts with preparing the plating baths that contain the tin/graphite/lead particles of known weight using the electroless mixture solution and reducing agent. A uniform copper film was formed on the tin/graphite/lead surface particles in about 10-15 min deposited from the hypophosphite based solutions from the alkaline baths. In addition, a complexing agent generally citrate and ammonium salts were also used to increase the particulate bonding. The complexing agents serve the function of preventing the precipitation of basic salts, as it also affects the deposition rate and properties. The bath ph level was usually maintained at the range between 8 and 10 using ammonium hydroxide. Lower deposition rates resulted when the ph level was adjusted with sodium hydroxide. Therefore, ammonium hydroxide was used for adjusting the ph of baths. The first bath was used to produce semibright tin/graphite/lead particles deposits containing approximately $4 \%$ phosphorus [23].

Deposition rates were increased with increased bath ph or hypophosphite concentration. The deposition rate in the first bath was increased from $5.6 \mu \mathrm{m} / \mathrm{h}$ to $10 \mu \mathrm{m} / \mathrm{h}$ at $85^{\circ} \mathrm{C}$ by simply adding organosulfur compound of $0.2 \mathrm{gm} . / \mathrm{cm}^{3}$ thiourea. The second bath contained less citrate than the first one which resulted in a substantially greater deposition rate. However, the resulting deposits had inferior physical properties. The last bath was a typical acid electroless tin/graphite/lead particles plating bath, using reducing agent that was incapable of yielding tin/graphite/lead particles deposits from acidic solution. Some of the reported advantages of electroless method were significant cost reduction, quality improvement of the deposited materials, and elimination of cross-contamination $[8,24-26]$. The weight of copper coatings was estimated by the difference in weight between the graphite particles before and after the electroless coating process.

The sintered density was obtained by both dimensional measurements as well as Archimedes density measurement technique. To compare the densification response of various compositions, the sintered densities were normalized with respect to the theoretical density. To take into account the influence of the initial as-pressed density, the compact sinterability was also expressed in terms of densification parameter, 


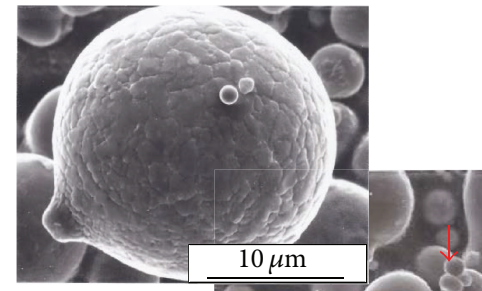

(b)

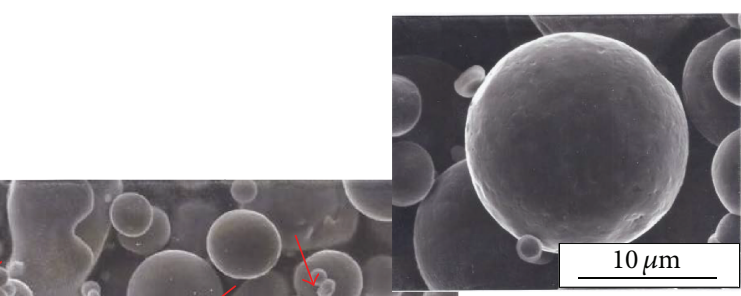

(c)

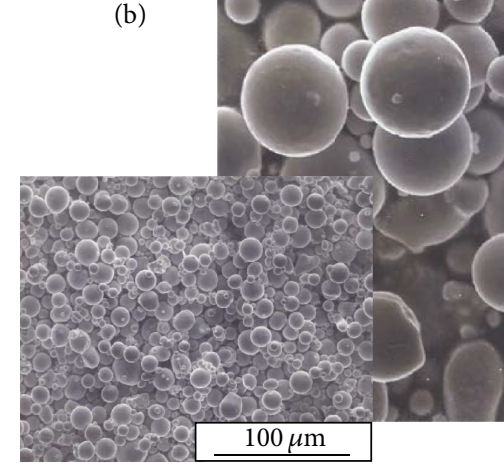

(d)

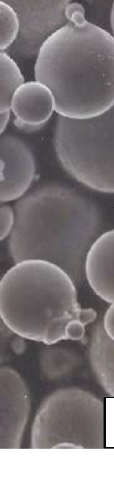

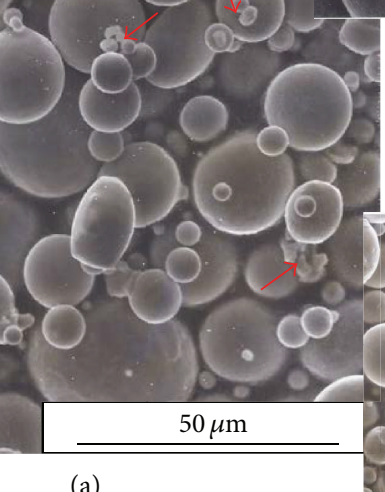

(a)

FIGURE 1: The (a) SEM surface microstructure of $\mathrm{Cu}-\mathrm{Sn}$ alloys as the red arrows points to the semisolid tin during the electroless process, (b) the graphite particle, (c) the lead particle as uniform spherical shape, (d) Cu-Sn alloys with graphite particles, and (e) Cu-Sn alloys with lead particles during the electroless process.

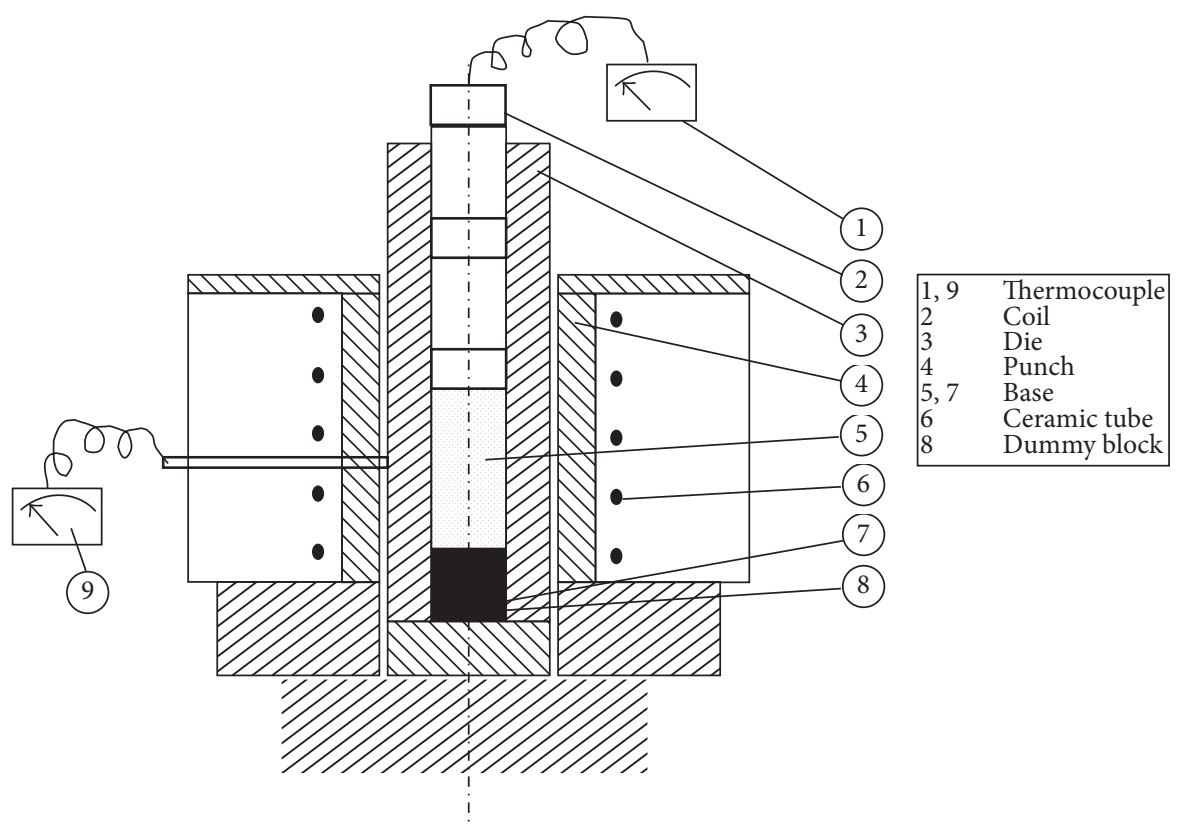

FIGURE 2: The die setup of the hot pressing technique.

which was calculated as the densification parameter, $\Delta D$ $=($ sintered density - green density $) /($ theoretical density green density), as the theoretical density $\left(\rho_{t}\right)$ was calculated using the following equation [8]:

$$
\rho_{t}=\frac{\sum_{i=1}^{n} \rho_{i}}{\sum_{i=1}^{n} \rho_{i} \cdot w_{i}}
$$

where $\rho_{i}$ and $w_{i}$ are the element density and weight fraction, respectively.
Hot compaction was performed in a single acting piston cylinder arrangement at room temperature in order to get $30 \mathrm{~mm}$ diameter and $50 \mathrm{~mm}$ height of the green compact, as shown in Figure 2. The die bore was smeared with intended powders reduce die wall friction, and the desired weights of mixed composites were used for each compact. A hydraulic testing machine of 200 tons capacity was used to perform the compaction of the alloy powder with constant cross head speed of $2 \mathrm{~mm} / \mathrm{min}$. The height of the green compact was 


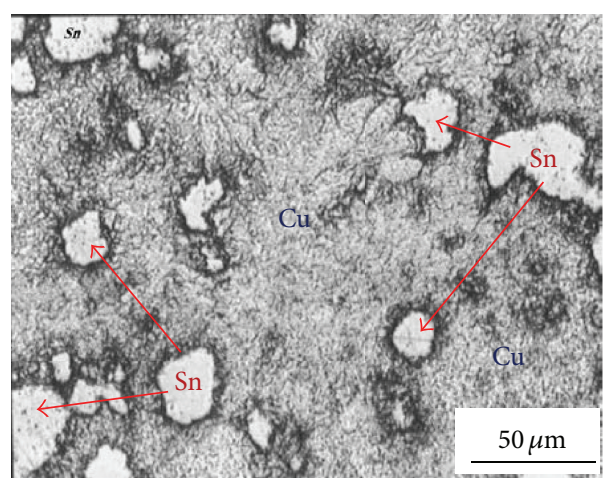

(a)

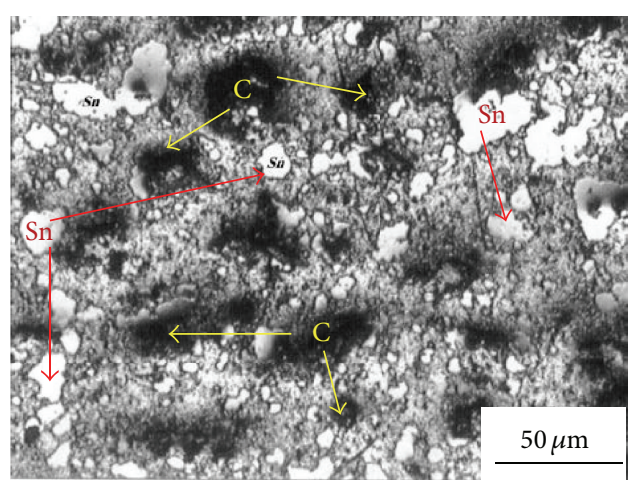

(b)

Figure 3: SEM micrographs of heat-treated (a) $90 \% \mathrm{Cu}-10 \% \mathrm{Sn}$ and (b) $85 \% \mathrm{Cu}-10 \% \mathrm{Sn}-5 \% \mathrm{C}$ alloys.

measured directly before and after ejecting from the die. The final height was also calculated from the load displacement curve. After unloading the elastic recovery of the compacts was neglected [17]. The die temperature was measured by means of a NiCr-Ni thermocouple, which was inserted through the die and kept near its cavity. The temperature was maintained at the required level with a tolerance of $\pm 5^{\circ} \mathrm{C}$. Different mold temperatures were tested up to $550^{\circ} \mathrm{C}$ at constant pressure of $314.38 \mathrm{MPa}$ and constant crosshead speed of $2 \mathrm{~mm} / \mathrm{min}$ [11]. All hot pressed MMCs were heattreated at about $550^{\circ} \mathrm{C}$ to allow the atoms to diffuse randomly into a uniform solid solution as liquid phase sintering [27, 28]. The tin melts to form a thin film surrounding the copper particles enhancing the alloying element bonding [28].

The setup was heated up to the preselected temperature which was kept constant for 30 minutes in order to homogenize the temperature throughout the powder alloy. The forming pressure was lowered for all tested hot components. After the compact operation, the samples were covered with aluminum foil and embedded in a graphite powder to protect its surface from the oxygen and nitrogen from the atmosphere during the sintering process. The specimens were sintered under liquid phase conditions at a constant heating rate of $20^{\circ} \mathrm{C} / \mathrm{min}$ to a temperature of $550^{\circ} \mathrm{C}$ for one hour allowing tin to melt and enhance the bonding of the copper matrix. The temperature was maintained at that level with a tolerance of $\pm 5^{\circ} \mathrm{C}$.

\section{Results and Discussion}

3.1. Optical Investigations. The microstructure investigation on the $\mathrm{Cu}-\mathrm{Sn}$ alloys was conducted using a Jeol 5400 SEM unit with a link EDS detector attachment to observe the particle morphology, particle size, particle shape, and agglomeration of particles after the fabrication process. Figure 3 shows the microstructures of the hot pressed $\mathrm{Cu}-\mathrm{Sn}$ alloys with various elemental powder additions as $\mathrm{C}$ and $\mathrm{Pb}$. The comparison between the pure $\mathrm{Cu}-\mathrm{Sn}$ alloys shown in Figures 3(a) and 3(b) indicates the enhancement of diffusion and alloy formation as results of liquid phase sintering [29]. Note that the large dark particle in Figure 3(b) presents the graphite particles.
The graphite black particles were seen in Figure 3(b), as the graphite was well combined with the matrix. Two phase microstructures were presented in Figure 4, as the microstructure included $\alpha$ - $\mathrm{Cu}$ (twining structure), graphite, and precipitates around the grain boundaries. SEM micrographs and EDX analysis of these specimens were given in Figures 4(a) and 4(b), respectively.

The Cu-Sn alloy (Figure 4(a)) was composed of the major bright phase zones and the others of gray ones. The matrix of these specimens was composed of the bright areas, and point 2 was $\mathrm{Cu}-6.8 \% \mathrm{Sn}$ which was a solid solution of $\mathrm{Sn}$ in $\mathrm{Cu}(\alpha-$ phase) whereas the gray particles have considerably higher Sn content as point 1 that corresponds to $\delta$-phase in the $\mathrm{Cu}-\mathrm{Sn}$ system. The gray phase in Figure 4(b) as points 1 and 2 was also $\mathrm{Sn}$-rich particles, containing $16.2 \%$. This also coincides with the composition of the $\delta$-phase.

Furthermore, the optical SEM microstructures of $80 \%$ $\mathrm{Cu}-10 \% \mathrm{Sn}-10 \% \mathrm{~Pb}$ and $90 \% \mathrm{Cu}-10 \% \mathrm{~Pb}$ alloys were shown in Figures 5(a) and 5(c), respectively. In Figure 5(a) the Sn-rich phase $(\delta)$ particles were observed as the addition to the $\mathrm{Pb}$ particles in the alloys. Separate $\mathrm{Pb}$ particles were defined in the microstructure as presented in higher magnification in Figure 5(b). The $\mathrm{Pb}$ solidified as almost pure lead forming globules at the copper grain boundaries. The structure consists of fine homogeneous $\mathrm{Cu}$ particles with some twining, as presented in Figure 5(c). It was noticed in higher magnifications (Figure 5(d)) for the $80 \% \mathrm{Cu}-10 \% \mathrm{Sn}$ $10 \% \mathrm{~Pb}$ alloys that the $\mathrm{Sn}$ particles form a uniform thin layer around the $\mathrm{Cu}$ particles as explained earlier during the liquid phase sintering process. A narrower $\mathrm{Cu}$ and $\mathrm{Sn}$ region, with higher inner connections between $\mathrm{Cu}$ and $\mathrm{Sn}$ particles, gives better mechanical interlock.

3.2. Vickers Microhardness Measurements. Vickers microhardness measurements were carried out for the different phase constituents of the hot pressed $\mathrm{Cu}-\mathrm{Sn}$ alloys, using a load of $10 \mathrm{Kg}$ for $20 \mathrm{sec}$ in time, and the speed of the indenter was $100 \mu \mathrm{m} / \mathrm{sec}$. To insure consistency throughout the material surface and homogeneity, a minimum of five readings were taken for each case and the average value was recorded. In all alloys the bright phase, which corresponds 


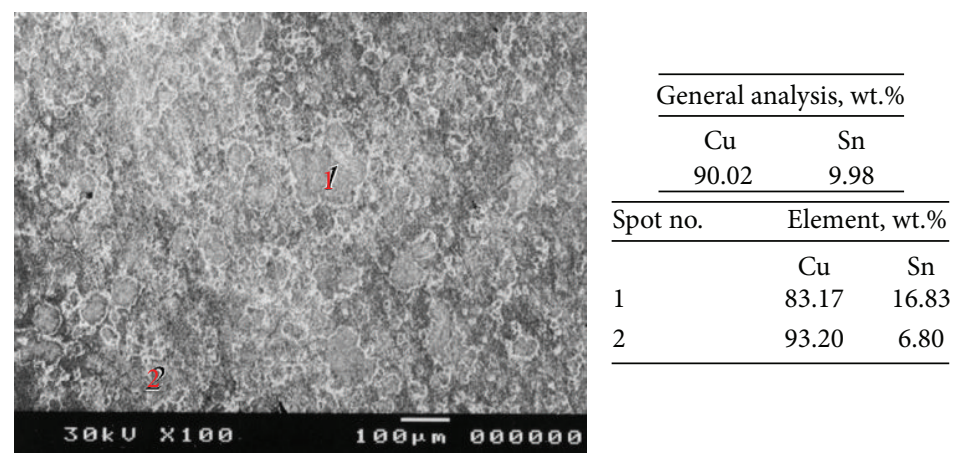

(a) $90 \% \mathrm{Cu}-10 \% \mathrm{Sn}$ alloy: points 1 and 2 refer to the regions analyzed by EDX
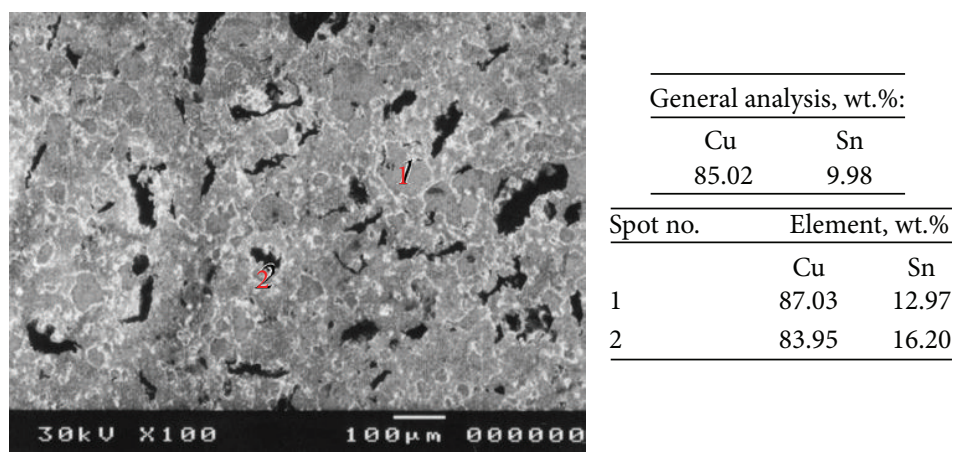

(b) $85 \% \mathrm{Cu}-10 \% \mathrm{Sn}-5 \% \mathrm{C}$ alloy: points 1 and 2 refer to the regions analyzed by EDX

Figure 4: SEM micrographs and EDX analysis of heat-treated (a) 90\% Cu-10\% Sn and (b) $85 \% \mathrm{Cu}-10 \% \mathrm{Sn}-5 \% \mathrm{C}$ alloys.
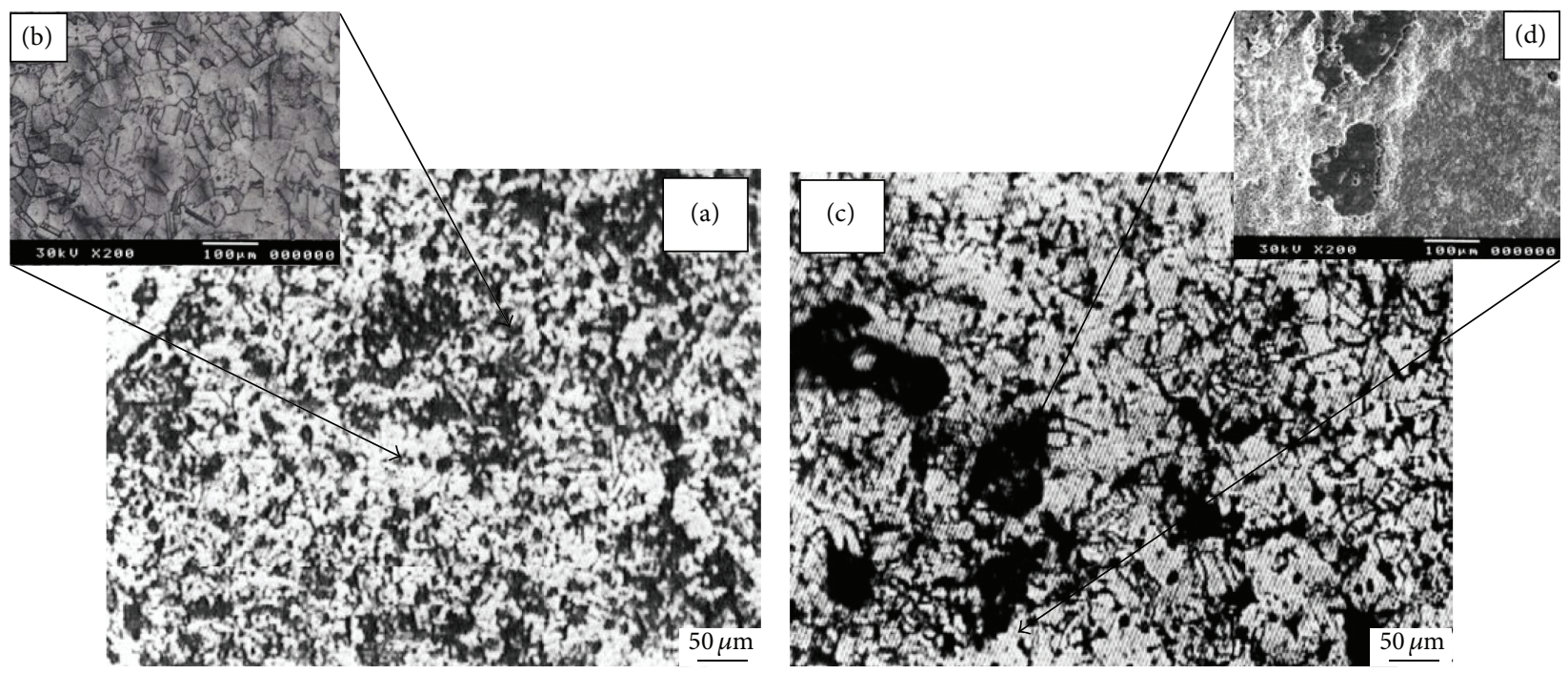

Figure 5: Optical SEM micrographs of heat-treated (a) $80 \% \mathrm{Cu}-10 \% \mathrm{Sn}-10 \% \mathrm{~Pb}$, (b) with higher magnification, (c) $90 \% \mathrm{Cu}-10 \% \mathrm{~Pb}$ alloys, and (d) with higher magnifications.

to $\delta$-phase, had Vickers microhardness measurements about two times greater than the corresponding matrix as presented in Table 1. It was observed that the $85 \% \mathrm{Cu}-10 \% \mathrm{Sn}-5 \% \mathrm{C}$ alloys exhibit lower hardness values compared to the other $\mathrm{Cu}-\mathrm{Sn}$ alloys for the matrix and $\delta$-phase. This decrease was attributed to the presence of graphite in the copper matrix.

As higher inner connections between $\mathrm{Cu}$ and $\mathrm{Sn}$ particles have the higher mechanical interlock of these alloys, the introduction of large $\mathrm{C}$ particles weakens the interlock 


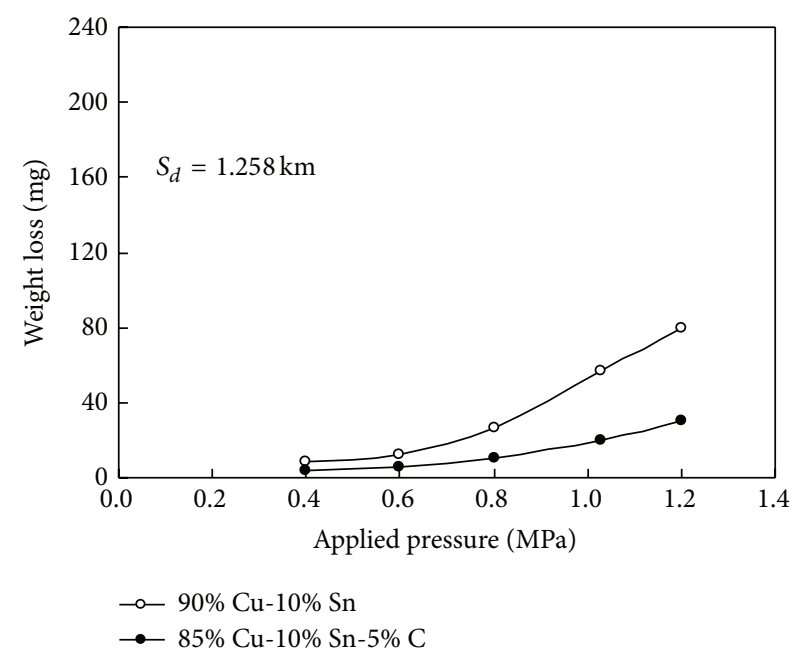

(a)

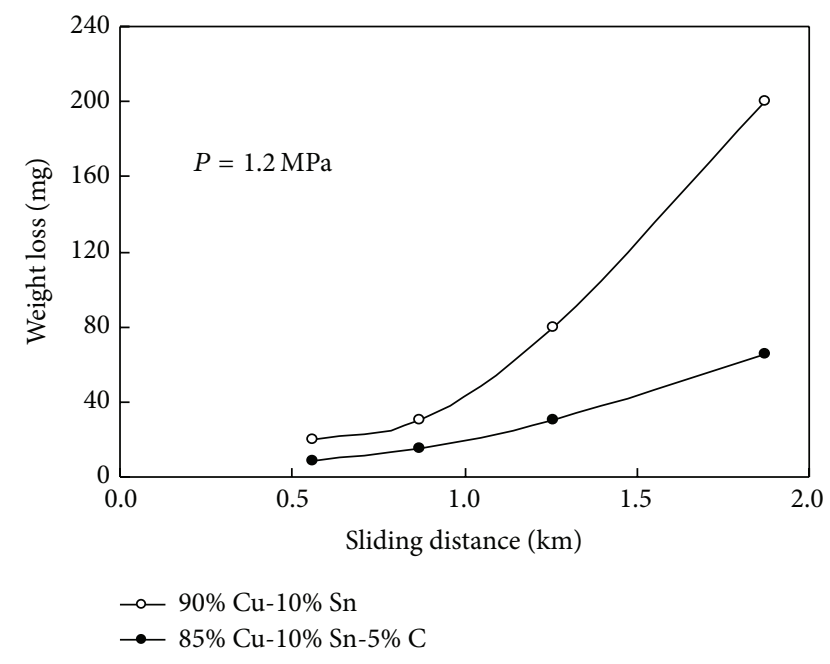

(b)

FIGURE 6: Weight losses in (mg) versus the applied pressure in $\mathrm{MPa}$ and the sliding distance in $\mathrm{Km}$ for the heat-treated (a) $90 \% \mathrm{Cu}-10 \% \mathrm{Sn}$ and (b) $85 \% \mathrm{Cu}-10 \% \mathrm{Sn}-5 \% \mathrm{C}$ alloys.

TABLE 1: Vickers microhardness values in $\mathrm{Kg} / \mathrm{mm}^{2}$ of hot pressed $\mathrm{Cu}-\mathrm{Sn}$ alloys.

\begin{tabular}{lcc}
\hline Alloys & \multicolumn{2}{c}{ Vickers microhardness $\left(H_{v}\right) \mathrm{Kg} / \mathrm{mm}^{2}$} \\
& Matrix $(\alpha-\mathrm{Cu})$ & Bright $(\delta$-phase $)$ \\
\hline $90 \% \mathrm{Cu}-10 \% \mathrm{Sn}$ & 112.2 & 246.6 \\
$85 \% \mathrm{Cu}-10 \% \mathrm{Sn}-5 \% \mathrm{C}$ & 83.7 & 162.7 \\
$80 \% \mathrm{Cu}-10 \% \mathrm{Sn}-10 \% \mathrm{~Pb}$ & 108.9 & 222.2 \\
$90 \% \mathrm{Cu}-10 \% \mathrm{~Pb}$ & 101.4 & 210.3 \\
\hline
\end{tabular}

compared to the effect of the smaller $\mathrm{Pb}$ particles as presented from the hardness values.

3.3. Wear Resistance. Wear measurements were performed by means of pin-on-disc method in dry conditions. The wear specimens were $8 \mathrm{~mm}$ in diameter and $12 \mathrm{~mm}$ in length. Surface preparation was conducted before the wear test, where each specimen was grinded with $1 \mu \mathrm{m}$ alumina suspension. Wear tests were conducted under dry sliding conditions, applied loads of $10 \mathrm{~N}$, and a constant sliding speed of $1.8 \mathrm{~m} / \mathrm{s}$. Wear loses were obtained by calculating the weight loss of the specimens before and after the testing using an electronic balance with a sensitivity of 0.1 milligram. The samples were cleaned in an acetone bath and dried using hot air before the tests to remove organic substances. The wear characteristics of $90 \% \mathrm{Cu}-10 \% \mathrm{Sn}$ and $85 \% \mathrm{Cu}-10 \% \mathrm{Sn}-$ $5 \% \mathrm{C}$ alloys were presented in Figure 6. The variations of weight loss of $\mathrm{Cu}$-based alloys with the contact pressure at sliding distance of $1.258 \mathrm{~km}$ were presented in Figure 6(a). It should be reported that a sudden acceleration in weight loss at contact pressure $0.8 \mathrm{MPa}$ for the $90 \% \mathrm{Cu}-10 \% \mathrm{Sn}$ alloy was observed. The $85 \% \mathrm{Cu}-10 \% \mathrm{Sn}-5 \% \mathrm{C}$ alloy exhibited considerably high wear resistance compared to the $90 \% \mathrm{Cu}-$ $10 \% \mathrm{Sn}$ alloy that can be seen in Figure 6(a). This may be attributed to the presence of graphite in the $\mathrm{Cu}$ matrix. It was observed that for the investigated alloy, in case of $90 \%$ $\mathrm{Cu}-10 \% \mathrm{Sn}$ alloy the aspirates of counterpart steel disc can abrade the copper alloy surface during dry sliding wear. Under a wear contact pressure of $1.2 \mathrm{MPa}$ the wear rate of $90 \% \mathrm{Cu}-10 \% \mathrm{Sn}$ alloy after $1.2 \mathrm{~km}$ sliding distance was about 3 times higher than that of $85 \% \mathrm{Cu}-10 \% \mathrm{Sn}-5 \%$ C alloy. Similar results were observed for high wear contact pressure up to 1.2 $\mathrm{MPa}$, as shown in Figure 6(b). This results in plastic strain localization in the subsurface region, leading to the formation of delaminating crack. The excessive delaminating of surface layers of copper alloy matrix leads to a high wear loss, which increases with increasing the contact pressure. Increasing the wear contact pressure tends to cause high plastic deformation of the matrix interface that can cause particle deformation. Thus, the wear rates of the alloys were mainly dependent on the level of the contact pressure.

The characteristics of wear resistance for both $\mathrm{Cu}$-based alloys (with and without graphite particles) were presented in Figure 6(b), showing the weight loss variations with respect to sliding wear distance at constant contact pressure of 1.2 $\mathrm{MPa}$. Using (1), the densification parameter (\%) was calculated for the selected $\mathrm{Cu}$-based alloys and presented in Table 2. It was observed the densification parameter increases with the addition of $\mathrm{Pb}$ significantly. For low sliding distance $(0.748$ and $1.2 \mathrm{~km}$ ) the $90 \% \mathrm{Cu}-10 \% \mathrm{Sn}$ alloy gives two times higher wear rate compared to $\mathrm{Cu}-\mathrm{Sn}-\mathrm{C}$ compact. For the long sliding distance, $1.87 \mathrm{~km}$, the presence of graphite leads to an increase in the wear resistance of the alloy by about three times.

The weight losses result in $90 \% \mathrm{Cu}-10 \% \mathrm{~Pb}$ and $\mathrm{Cu}-\mathrm{Sn}-\mathrm{Pb}$ alloys with respect to sliding wear distance at constant contact pressure of 1.2 MPa as presented in Figure 7. The weight losses for $90 \% \mathrm{Cu}-10 \% \mathrm{~Pb}$ alloy were slightly lower than that for $80 \% \mathrm{Cu}-10 \% \mathrm{Sn}-10 \% \mathrm{~Pb}$ alloy. Thus $\mathrm{Sn}$ in $90 \% \mathrm{Cu}-10 \% \mathrm{~Pb}$ compacts was harmful to wear resistance.

For comparison purposes, the weight loss for $\mathrm{Cu}$-based matrix alloys, at sliding distance of $1.258 \mathrm{~km}$ and contact 
TABLE 2: The weight losses in $\mathrm{mg}$ at sliding distance of $1.258 \mathrm{~km}$ and contact pressure of 1.2 $\mathrm{MPa}$ and the densification parameter for all $\mathrm{Cu}$-based alloys.

\begin{tabular}{lcc}
\hline Alloy composition, wt.\% & Weight losses, mg & $\begin{array}{c}\text { Densification } \\
\text { parameter, \% }\end{array}$ \\
\hline 90\% Cu-10\% Sn & 80 & 12.01 \\
$85 \% \mathrm{Cu}-10 \% \mathrm{Sn}-5 \% \mathrm{C}$ & 30 & 14.61 \\
$80 \% \mathrm{Cu}-10 \% \mathrm{Sn}-10 \% \mathrm{~Pb}$ & 178 & 34.03 \\
$90 \% \mathrm{Cu}-10 \% \mathrm{~Pb}$ & 115 & 36.45 \\
\hline
\end{tabular}

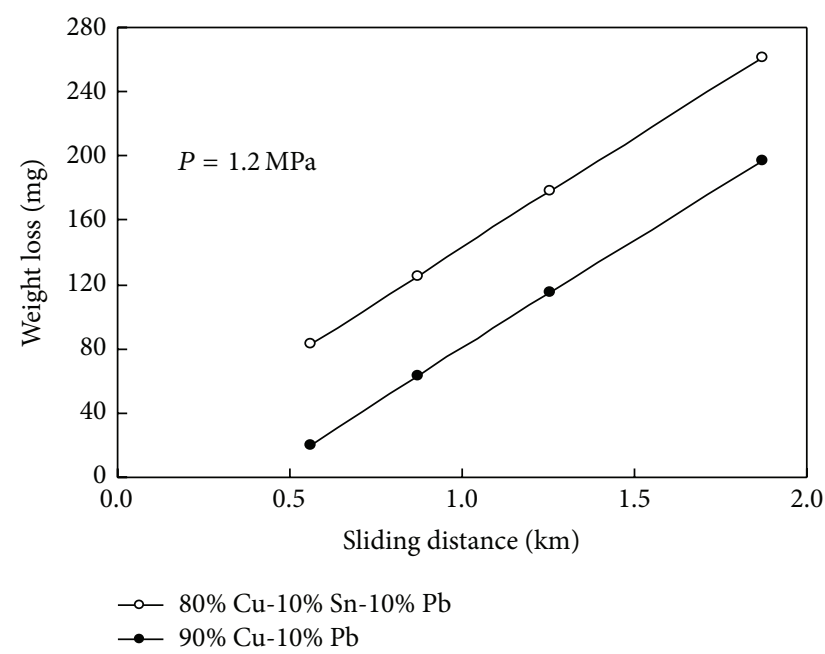

FIGURE 7: Weight losses in mg versus sliding distance in $\mathrm{Km}$ for the heat-treated $80 \% \mathrm{Cu}-10 \% \mathrm{Sn}-10 \% \mathrm{~Pb}$ and $90 \% \mathrm{Cu}-10 \% \mathrm{~Pb}$ alloys.

pressure of 1.2 $\mathrm{MPa}$, and the densification parameter were presented in Table 2 for all $\mathrm{Cu}$-based alloys. It could be concluded from the wear resistance values for the $\mathrm{Cu}$-based alloys that the addition of $\mathrm{C}$ elements improves the wear resistance of the alloys. On the contrary, the addition of $\mathrm{Pb}$ elements degrades the wear resistance of the alloys.

Low wear losses of the counter surface were found with the existence of the $\mathrm{C}$ large particles as affected by the particle agglomeration. The introduction of large $\mathrm{C}$ particles weakens the interlock inner connections between the $\mathrm{Cu}$ and $\mathrm{Sn}$ particles resulting in low hardness, but the large particles losses were reduced at these wear losses conditions. This was on the contrary when compared to the effect of introduction of the smaller $\mathrm{Pb}$ particles as observed in surface alloyed coated particles $[30,31]$.

3.4. Compression Mechanical Measurements. Cylindrical specimens of aspect ratio of $h_{o} / d_{o}=1.5\left(h_{o}\right.$ and $d_{o}$ were the original height and diameter of the specimen, resp.) were tested under frictionless conditions at the compression platen interface. The tests were carried out at room temperature using MTS Testing Machine (Model 610) fitted with a $160 \mathrm{KN}$ load cell operating in the displacement control mode. The stress-strain responses of $\mathrm{Cu}$-based alloys were measured from uniaxially compression testing performed accordingly
TABLE 3: The compressive test results for the Cu-based alloys.

\begin{tabular}{lccc}
\hline Alloy & $\begin{array}{c}\text { Yield } \\
\text { strength } \\
\sigma_{y}, \mathrm{MPa}\end{array}$ & $\begin{array}{c}\text { Ultimate } \\
\text { strength } \\
\sigma_{\mathrm{UTS}}, \mathrm{MPa}\end{array}$ & Elongation\% \\
\hline $90 \% \mathrm{Cu}-10 \% \mathrm{Sn}$ & 210 & 586 & 23 \\
$85 \% \mathrm{Cu}-10 \% \mathrm{Sn}-5 \% \mathrm{C}$ & 194 & 325 & 9 \\
$80 \% \mathrm{Cu}-10 \% \mathrm{Sn}-10 \% \mathrm{~Pb}$ & 207 & 583 & 22.8 \\
$90 \% \mathrm{Cu}-10 \% \mathrm{~Pb}$ & 201 & 669 & 39 \\
\hline
\end{tabular}

to ASTM standard E-9 for metals. The cross head speed was adjusted to give an average strain rate of $7.6 \times 10^{-4} \mathrm{~s}^{-1}$ across the specimen height. The test was terminated as the first surface crack was observed. The tests were repeated with three samples for each experiment. Figure 8 presents the experimental results of the flow curve versus the strain obtained by the compression tests for $90 \% \mathrm{Cu}-10 \% \mathrm{Sn}$ with no additions, $85 \%$ Cu-10\% Sn-5\% C, 80\% Cu-10\% $\mathrm{Sn}-10 \% \mathrm{~Pb}$, and $90 \% \mathrm{Cu}-10 \% \mathrm{~Pb}$ weight percentages alloys, respectively. The $\mathrm{Cu}-\mathrm{Sn}$ alloy indicates that high strength and remarkable strain with respect to the $85 \% \mathrm{Cu}-10 \% \mathrm{Sn}-5 \%$ $\mathrm{C}$ alloy in Figure $8(\mathrm{a})$. Brittle fracture was observed for the $85 \% \mathrm{Cu}-10 \% \mathrm{Sn}-5 \% \mathrm{C}$ alloy. The strength and ductility were substantially affected by the addition of $\mathrm{Sn}$ and $\mathrm{Pb}$ particles, as presented in Figure 8(b). The ductility of the $90 \% \mathrm{Cu}-10 \% \mathrm{~Pb}$ alloys, as in Figure $8(\mathrm{a})$, demonstrated improvement over the $90 \% \mathrm{Cu}-10 \% \mathrm{Sn}$ alloys, as presented in Figure $8(\mathrm{~b})$. In addition, the $\mathrm{Pb}$ addition for the $\mathrm{Cu}-\mathrm{Sn}$ alloys did not show any improvements in the strength or ductility as seen in Figure 8(b). Comparison of the yield strength, ultimate strength, and the elongation percentage for the tested materials produced by the hot pressing PM technique were extracted as in Table 3.

Similarly, with the introduction to the $C$ large particles to the $\mathrm{Cu}-\mathrm{Sn}$ alloys the stress-strain response tends to decrease. As explained through the hardness the addition of $\mathrm{C}$ weakens the interlock inner connections between the $\mathrm{Cu}$ and $\mathrm{Sn}$ particles, whereas the addition of $\mathrm{Pb}$ enhances it.

3.5. Fracture Surface. Copper particles coated with thin tin were relatively small, irregularly shaped, and tending to agglomerate. The $\mathrm{Cu}$ phase was dispersed with many pools or lakes present in the compression fractured samples. The high hardness may be attributed to the process of continuous crystallization during the plastic deformation. $\mathrm{Cu}-\mathrm{Sn}$ alloys with the addition of $\mathrm{C}$ and $\mathrm{Pb}$ have been observed to undergo mechanically induced fine crystallization as presented in Figures 9(a) and 9(b). Fine crystal precipitation in $\mathrm{Cu}-\mathrm{Sn}$ alloys was also observed within vein protrusions on the compression fracture surface and along crack propagation paths, as well as within shear bands resulting from bending [32]. The 85\% Cu-10\% Sn-5\% C and 80\% Cu-10\% Sn-10\% Pb alloys show an apparently classical inclined fracture surface, about $45^{\circ}$ with the applied stress axis, which was similar to that encountered for a variety of hard metals [33] as presented in Figures 9(a) and 9(b). 


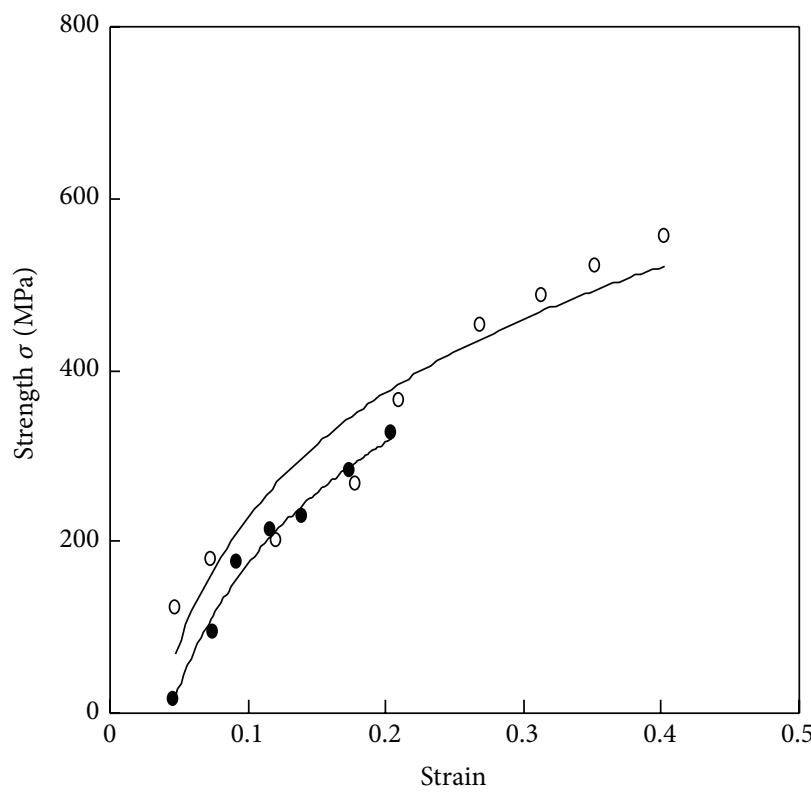

- $90 \% \mathrm{Cu}-10 \% \mathrm{Sn}$

- $85 \% \mathrm{Cu}-10 \% \mathrm{Sn}-5 \% \mathrm{C}$

(a)

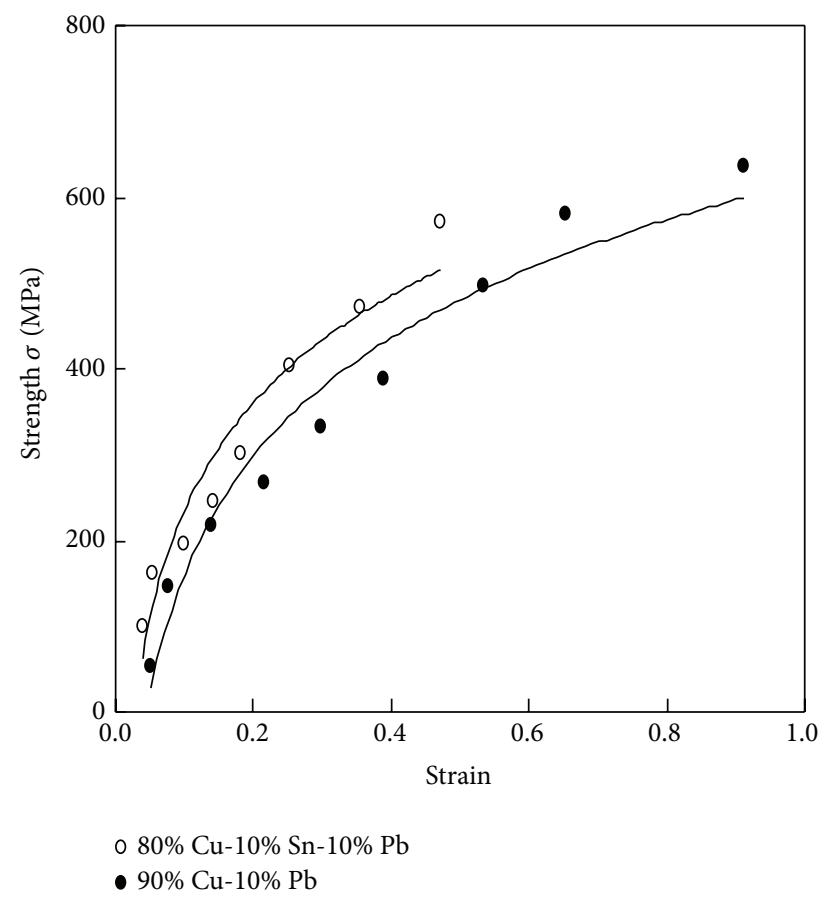

(b)

Figure 8: The stress-strain curves for the heat-treated (a) $90 \% \mathrm{Cu}-10 \% \mathrm{Sn}$ and $85 \% \mathrm{Cu}-10 \% \mathrm{Sn}-5 \% \mathrm{C}$ and (b) $80 \% \mathrm{Cu}-10 \% \mathrm{Sn}-10 \% \mathrm{~Pb}$ and $90 \% \mathrm{Cu}-10 \% \mathrm{~Pb}$ alloys.
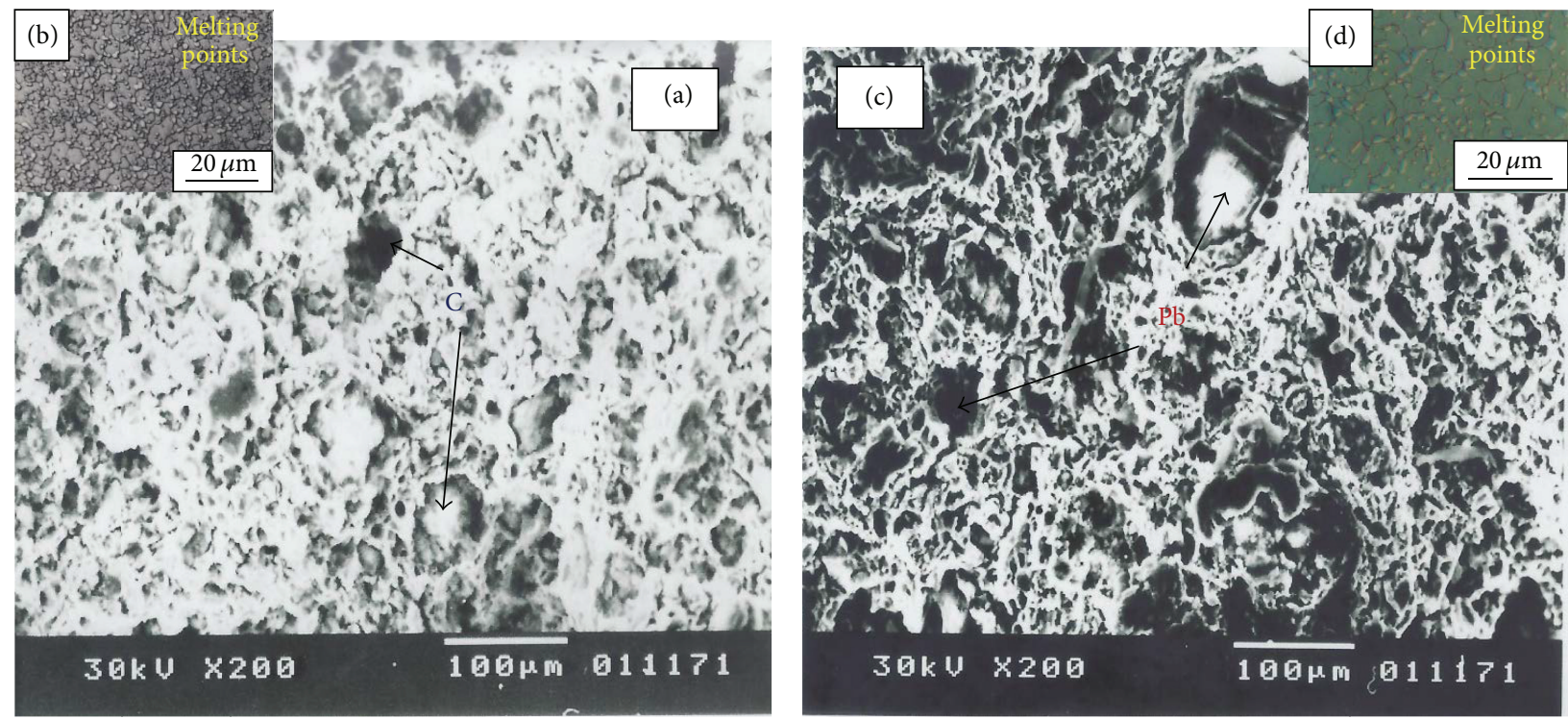

FIGURE 9: SEM image of irregularity and rough morphology of the fracture surface for (a) compression fractured $85 \% \mathrm{Cu}-10 \% \mathrm{Sn}-5 \% \mathrm{C}$ alloys, (b) higher magnification showing melting droplets morphology, (c) compression fractured $80 \% \mathrm{Cu}-10 \% \mathrm{Sn}-10 \% \mathrm{~Pb}$ alloys, and (d) higher magnification showing melting droplets morphology.

Evidence of severe melting spots were noticed as shown in the higher magnifications of the fracture surface of $85 \%$ $\mathrm{Cu}-10 \% \mathrm{Sn}-5 \% \mathrm{C}$ and $80 \% \mathrm{Cu}-10 \% \mathrm{Sn}-10 \% \mathrm{~Pb}$ alloys in Figures 9 (b) and 9(d). This could be due to the release of the load at the final event of fracture in this limited area. The fracture surface was linked to the formation of the very fine particles in the alloys. This enhances the homogeneity of the deformation, leading to the formation of multiple shear planes instead of a single shear plane normally encountered in $85 \% \mathrm{Cu}-10 \% \mathrm{Sn}-5 \% \mathrm{C}$ and $80 \% \mathrm{Cu}-10 \% \mathrm{Sn}-10 \% \mathrm{~Pb}$ alloys as presented in Figures 9(a) and 9(c). The viscosity of the $\mathrm{Cu}$ Sn alloys in the region where fewer fine particles exist will 
be lower. This leads to a less critical shear stress and a more readily plastic deformation $[34,35]$.

\section{Conclusions}

Based on the results of the present study, the following conclusions can be summarized:

(1) The $\mathrm{Cu}$-Sn powder alloys were successfully fabricated using hot pressing technique with the additions of $\mathrm{C}$ and $\mathrm{Pb}$.

(2) The hot pressed specimens $\mathrm{Cu}-\mathrm{Sn}$ alloys included intermetallic phases such as $\alpha$-Cu and $\delta$-phase, which were homogeneously distributed.

(3) As higher inner connections between $\mathrm{Cu}$ and $\mathrm{Sn}$ particles have the higher mechanical interlock of these alloys, the introduction of large $\mathrm{C}$ particles weakens the interlock compared to the effect of the smaller $\mathrm{Pb}$ particles as presented from the hardness values.

(4) The effect of adding $\mathrm{C}$ improves the wear resistance of the $\mathrm{Cu}-\mathrm{Sn}$ alloys compared to alloys without graphite addition by three times. Compressive properties of $\mathrm{Cu}-\mathrm{Sn}$-C alloys were lower than those of $\mathrm{Cu}-\mathrm{Sn}$ alloys.

(5) Significant differences in the mechanical properties such as yield strength, ultimate, and elongation percent of $\mathrm{Cu}-\mathrm{Sn}$ and $\mathrm{Cu}-\mathrm{Sn}-\mathrm{Pb}$ alloys were noticed. $\mathrm{Cu}-$ $\mathrm{Pb}$ alloy had higher mechanical properties than those other compacts. Also, the wear resistance of $\mathrm{Cu}-\mathrm{Sn}$ alloy was considerably higher compared to the other alloys.

(6) Evidence of severe melting spots was noticed in the higher magnifications of the compression fracture surface of $85 \% \mathrm{Cu}-10 \% \mathrm{Sn}-5 \% \mathrm{C}$ and $80 \% \mathrm{Cu}-10 \% \mathrm{Sn}$ $10 \% \mathrm{~Pb}$ alloys, as it could be explained by the release of the load at the final event of fracture in this limited area.

\section{Competing Interests}

The authors declare that they have no competing interests.

\section{References}

[1] B. D. Long, R. Othman, H. Zuhailawati, and M. Umemoto, "Comparison of two powder processing techniques on the properties of $\mathrm{Cu}-\mathrm{NbC}$ composites," Advances in Materials Science and Engineering, vol. 2014, Article ID 160580, 6 pages, 2014.

[2] H. Rudianto, G. J. Jang, S. S. Yang, Y. J. Kim, and I. Dlouhy, "Evaluation of sintering behavior of premix Al-Zn-Mg-Cu alloy powder," Advances in Materials Science and Engineering, vol. 2015, Article ID 987687, 8 pages, 2015.

[3] A. Es. Nassef, "Effect of $\mathrm{Pb}$ and $\mathrm{C}$ addition on mechanical behavior of hot-pressed Cu-Sn powderalloys," in Proceedings of the International Conference on Mechanical Design and Production, MDP-8, vol. 46, pp. 69-77, Cairo University, January 2004.

[4] M. M. De Campos and M. D. C. Ferreira, "A comparative analysis of the flow properties between two alumina-based dry powders," Advances in Materials Science and Engineering, vol. 2013, Article ID 519846, 7 pages, 2013.

[5] L. Robbiola, J.-M. Blengino, and C. Fiaud, "Morphology and mechanisms of formation of natural patinas on archaeological Cu-Sn alloys," Corrosion Science, vol. 40, no. 12, pp. 2083-2111, 1998.

[6] M. A. El-Hadek and M. Kassem, "Failure behavior of Cu-Ti-Zrbased bulk metallic glass alloys," Journal of Materials Science, vol. 44, no. 4, pp. 1127-1136, 2009.

[7] M. A. El-Hadek and S. H. Kaytbay, "Fracture properties of SPS tungsten copper powder composites," Metallurgical and Materials Transactions A: Physical Metallurgy and Materials Science, vol. 44, no. 1, pp. 544-551, 2013.

[8] M. A. El-Hadek and S. H. Kaytbay, " $\mathrm{Al}_{2} \mathrm{O}_{3}$ particle size effect on reinforced copper alloys: an experimental study," Strain, vol. 45, no. 6, pp. 506-515, 2009.

[9] A. F. Holleman, E. Wiberg, and N. Wiberg, “Tin," in Lehrbuch der Anorganischen Chemie, pp. 793-800, Walter de Gruyter, Berlin, Germany, 91th-100th edition, 1985 (German).

[10] W. Zhai, W. L. Wang, D. L. Geng, and B. Wei, "A DSC analysis of thermodynamic properties and solidification characteristics for binary Cu-Sn alloys," Acta Materialia, vol. 60, no. 19, pp. 65186527, 2012.

[11] A. A. El-Daly, A. E. Hammad, A. Fawzy, and D. A. Nasrallh, "Microstructure, mechanical properties, and deformation behavior of $\mathrm{Sn}-1.0 \mathrm{Ag}-0.5 \mathrm{Cu}$ solder after $\mathrm{Ni}$ and $\mathrm{Sb}$ additions," Materials \& Design, vol. 43, pp. 40-49, 2013.

[12] H. Xie, N. Chawla, and K. Mirpuri, "Thermal and mechanical stability of Ce-containing Sn-3.9 Ag-0.7 Cu lead-free solder on $\mathrm{Cu}$ and electroless Ni-P metallizations," Journal of Electronic Materials, vol. 41, no. 12, pp. 3249-3258, 2012.

[13] B. L. Silva, N. Cheung, A. Garcia, and J. E. Spinelli, "Thermal parameters, microstructure, and mechanical properties of directionally solidified $\mathrm{Sn}-0.7 \mathrm{wt} . \% \mathrm{Cu}$ solder alloys containing 0 ppm to 1000 ppm Ni," Journal of Electronic Materials, vol. 42, no. 1, pp. 179-191, 2013.

[14] J. H. Kim, Y. S. Jang, B. K. Park, and Y. C. Kang, "Electrochemical properties of C-coated Cu6Sn5 nanoparticles dispersed on carbon matrix prepared by spray drying process," International Journal of Electrochemical Science, vol. 8, no. 1, pp. 1067-1078, 2013.

[15] B. D. Polat, N. Sezgin, Ö. Keles, A. Abouimrane, and K. Amine, "Use of $\mathrm{Cu}-\mathrm{Sn} / \mathrm{C}$ multilayered thin film in lithium ion batteries," in Proceedings of the Honolulu PRiME Meeting, no. 10, pp. 968-968, The Electrochemical Society, Honolulu, Hawaii, USA, June 2012.

[16] J. S. Thorne, R. A. Dunlap, and M. N. Obrovac, “(Cu6Sn5)1-xCx active/inactive nanocomposite negative electrodes for $\mathrm{Na}$-ion batteries," Electrochimica Acta, vol. 112, pp. 133-137, 2013.

[17] D. C. Walker, W. F. Caley, and M. Brochu, "Selective laser sintering of composite copper-tin powders," Journal of Materials Research, vol. 29, no. 17, pp. 1997-2005, 2014.

[18] J. Konstantanty, A. Bunsch, and A. Cias, "Factors affecting hardness and ductility of hot-pressed cobalt powders," Powder Metallurgy International, vol. 23, no. 6, pp. 354-356, 1991.

[19] M. I. Yehia and M. E. Abdel Rahman, "Production of biometallic parts from powders utilizing the powder metallurgy technique," in Proceedings of the 3rd International Conference on Mechanical Engineering Advanced Technology for Industrial Production (MEATIP '02), pp. 46-55, Assiut University, Assuit, Egypt, December 2002. 
[20] F. Z. Lemmadi, A. Chala, S. Ferhati, F. Chabane, and S. Benramache, "Structural and mechanical behavior during quenching of 40CrMoV5 steel," Journal of Science and Engineering, vol. 3, no. 1, pp. 1-6, 2013.

[21] S. F. Moustafa, S. A. El-Badry, and A. M. Sand, "The effect of graphite without and with $\mathrm{Cu}$-coating on consolidation behavior and sintering of Cu-graphite Composite," in Proceedings of the 6th International Conference on Production Engineering Design and Control (PEDAC '97), pp. 267-277, Alexandria, Egypt, February 1997.

[22] A. Nassef and M. El-Hadek, "Mechanics of hot pressed aluminum composites," The International Journal of Advanced Manufacturing Technology, vol. 76, no. 9-12, pp. 1905-1912, 2014.

[23] M. A. El-Hadek and S. Kaytbay, "Mechanical and physical characterization of copper foam," International Journal of Mechanics and Materials in Design, vol. 4, no. 1, pp. 63-69, 2008.

[24] A. Fathy, F. Shehata, M. Abdelhameed, and M. Elmahdy, "Compressive and wear resistance of nanometric alumina reinforced copper matrix composites," Materials \& Design, vol. 36, pp. 100$107,2012$.

[25] F. Abd El-Salam, A. Fawzy, M. T. Mostafa, and R. H. Nada, "Resoftening and resistivity variation in thermally deformed $\mathrm{Cu}-\mathrm{Sn}$ and $\mathrm{Cu}-\mathrm{Sn}-\mathrm{Zn}$ alloys," Egyptian Journal of Solids, vol. 23, no. 2, pp. 341-353, 2000.

[26] A. Veillere, J.-M. Heintza, N. Chandrab et al., "Influence of the interface structure on the thermo-mechanical properties of $\mathrm{Cu}$ $\mathrm{X}(\mathrm{X}=\mathrm{Cr}$ or $\mathrm{B}) /$ carbon fiber composites," Materials Research Bulletin, vol. 47, no. 2, pp. 375-380, 2012.

[27] R. M. German, Liquid Phase Sintering, Springer Science \& Business Media, Boston, Mass, USA, 2013.

[28] C. M. Sutter-Fella, J. A. Stückelberger, H. Hagendorfer et al., "Sodium assisted sintering of chalcogenides and its application to solution processed $\mathrm{Cu}_{2} \mathrm{ZnSn}(\mathrm{S}, \mathrm{Se})_{4}$ thin film solar cells," Chemistry of Materials, vol. 26, no. 3, pp. 1420-1425, 2014.

[29] G. Sethi, A. Upadhyaya, and D. Agrawal, "Microwave and conventional sintering of premixed and prealloyed $\mathrm{Cu}-12 \mathrm{Sn}$ Bronze," Science of Sintering, vol. 35, no. 2, pp. 49-65, 2003.

[30] J. V. Rau, A. Latini, R. Teghil et al., "Superhard tungsten tetraboride films prepared by pulsed laser deposition method," ACS Applied Materials and Interfaces, vol. 3, no. 9, pp. 37383743, 2011.

[31] J. D. Bressan, D. P. Daros, A. Sokolowski, R. A. Mesquita, and C. A. Barbosa, "Influence of hardness on the wear resistance of 17-4 PH stainless steel evaluated by the pin-on-disc testing," Journal of Materials Processing Technology, vol. 205, no. 1-3, pp. 353-359, 2008.

[32] Q. K. Zhang and Z. F. Zhang, "Fracture mechanism and strength-influencing factors of $\mathrm{Cu} / \mathrm{Sn}-4 \mathrm{Ag}$ solder joints aged for different times," Journal of Alloys and Compounds, vol. 485, no. 1-2, pp. 853-861, 2009.

[33] K. S. Kumar, L. Reinbold, A. F. Bower, and E. Chason, "Plastic deformation processes in $\mathrm{Cu} / \mathrm{Sn}$ bimetallic films," Journal of Materials Research, vol. 23, no. 11, pp. 2916-2934, 2008.

[34] S. Kaytbay and M. El-Hadek, "Wear resistance and fracture mechanics of WC-Co composites," International Journal of Materials Research, vol. 105, no. 6, pp. 557-565, 2014.

[35] M. A. El-Hadek and M. A. Kassem, "Mechanics of Ti-Ni BMG-based alloys: experimental study," Journal of Engineering Mechanics, vol. 140, no. 1, pp. 53-60, 2014. 

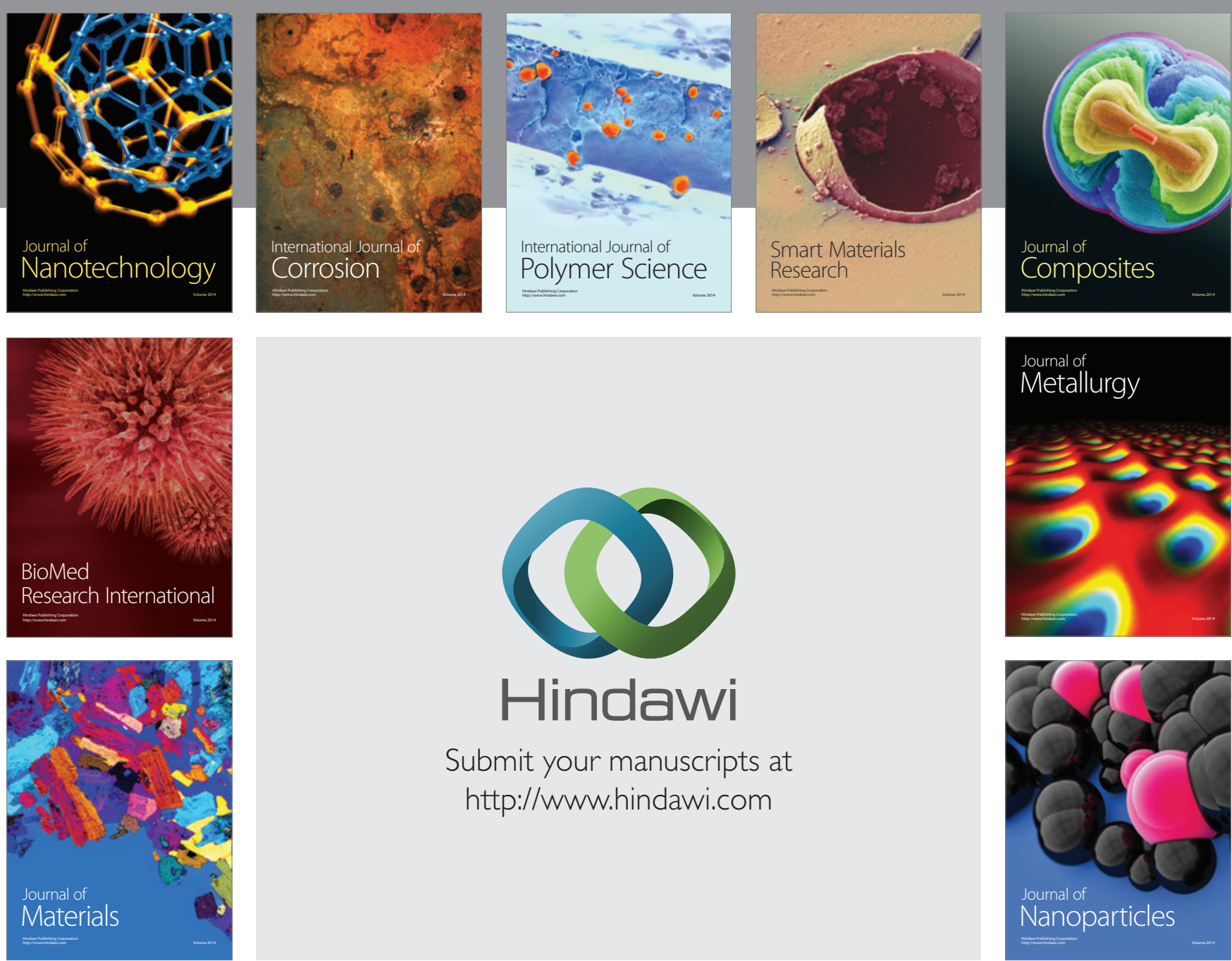

\section{Hindawi}

Submit your manuscripts at

http://www.hindawi.com

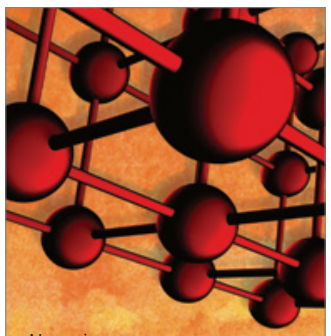

Materials Science and Engineering
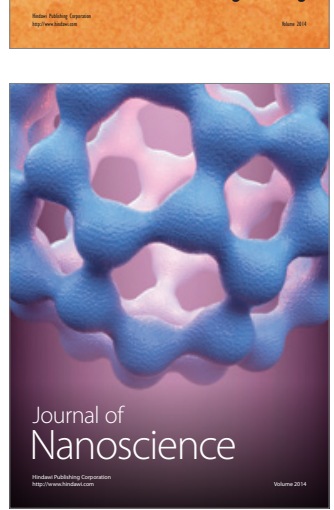
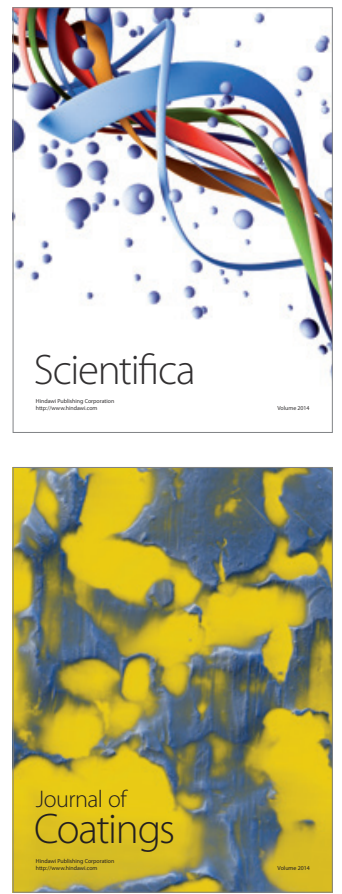
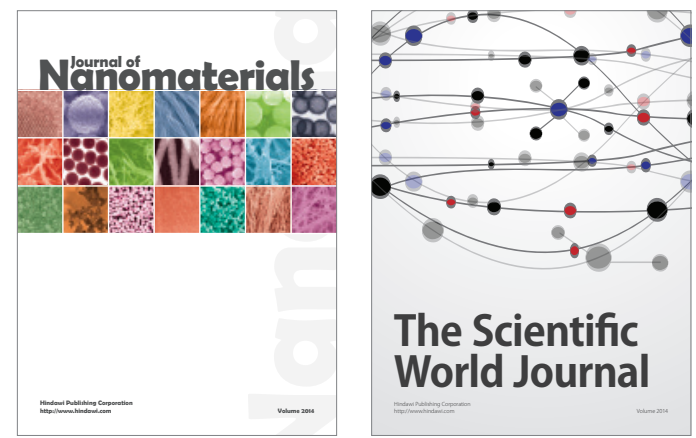

The Scientific World Journal
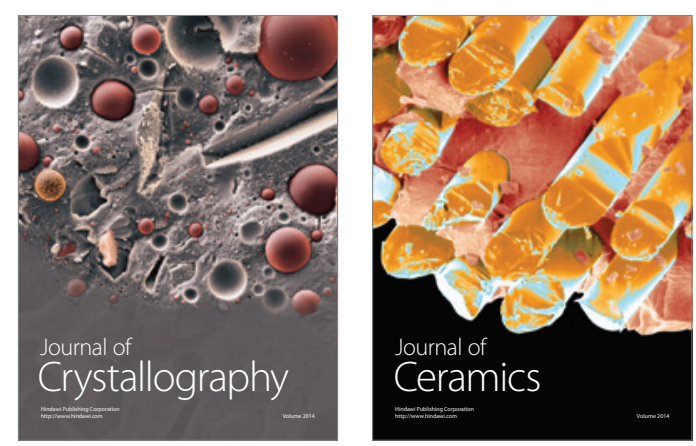
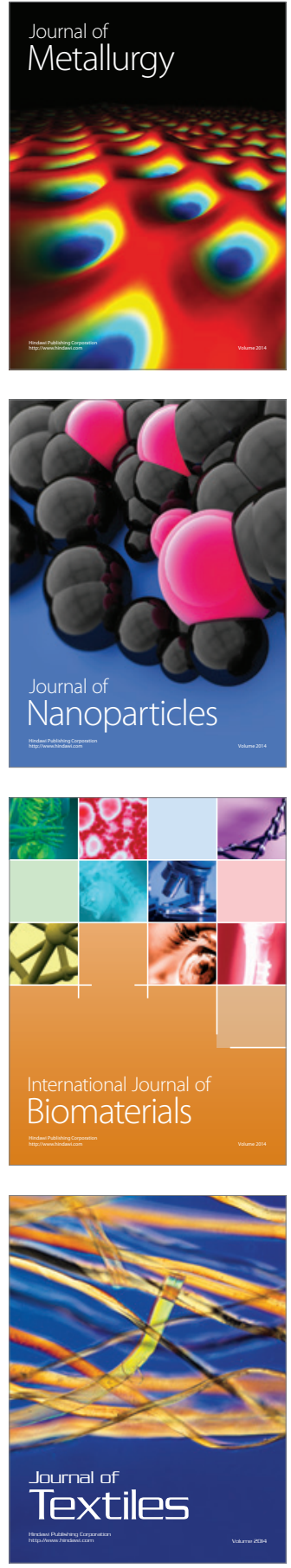